\title{
The Relation Between Knowledge and The Role of A Family With Obedience Diet at The Client Type 2 Diabetes Mellitus
}

\author{
Rian Tasalim ${ }^{1}$, Muhammad Riduansyah ${ }^{2}$, Sugiarto $^{3}$ \\ \{rian.tasalim@yahoo.com ${ }^{1}$,riduansyah@yahoo.com ${ }^{2}$, ns.suugi@yahoo.com ${ }^{3}$ \} \\ ${ }^{1,2}$ Lecture of Nursing Department, Universitas Sari Mulia, Indonesia \\ ${ }^{3}$ Lecture of Nursing Department, Universitas Alma Ata, Indonesia \\ *rian.tasalim@yahoo.com
}

\begin{abstract}
Diabetes mellitus is a chronic disease that is on the rise around the world. Based on data from Indonesia WHO currently is ranked sixth. Especially in type 2 diabetes mellitus commonly undiagnosed after age 40 years. Diet is part of the therapy of diabetes mellitus, but non-obedience to the diet is one of the barriers to achieving treatment of diabetes mellitus. In addition, the role of the family is important to motivate the clients in carrying out treatment and diet. Objective to know the relationship between knowledge and the role of families with Diet Obedience on the client we based on type 2 Diabetes mellitus. This research is a survey with analytic, cross-sectional approach. The number of samples as many as 77 people using accidental sampling techniques. Research instruments such as questionnaires. Data analysis using the kumputer program with the spearman rank correlation test $\alpha=5 \%$. (1) a good level of knowledge of respondents about 44 people (51.7\%); (2) the role of positive family some 43 people (34.7\%) respondents; (3) Not complying with a number of 40 people diet respondents $(32.2 \%)$; (4) there is a meaningful relationship between diet obedience knowledge with DM type 2 (the value of the sig $(2$-tailed) $=0.036$; correalation value $=0.239$ ); $(5)$ there is a meaningful relationship between the role of the family diet obedience with DM type 2 (the value of the sig $(2$-tailed $)=0.047$; correalation's value $=0.227)$. Based on the test results kolerasi Spearman Rank (Rho), there is a meaningful relationship between the knowledge and the role of the family Diet obedience on clients with type 2 Diabetes mellitus in Puskesmas Pekauman.
\end{abstract}

Keywords: knowledge, the role of the family, and obedience diet.

\section{Introduction}

Diabetes mellitus is a chronic disease that continues to increase throughout the world. In the United States, an estimated 23.6 million people use diabetes mellitus, $90-95 \%$ are type $2 \mathrm{DM}^{(2)}$. Data from the World Health Organization (WHO), diabetes mellitus in Indonesia is ranked sixth, after India, China, Russia, Japan and Brazil. Meanwhile, a study conducted by the Ministry of Health in 2008 found that $11.4 \%$ of the Indonesian population used prediabetes. Data from the International Diabetes Federation (FDI), diabetes atlas shows 285 million people diagnosed with diabetes turns out to be more young people. More than half of this is the young population between 20-60 years. The data also shows that Indonesia is included in the list of 10 countries with the highest incidence of diabetes, with India ranked first, second China, and US third ${ }^{(21)}$. The number of clients with diabetes mellitus in 2000 in the world including Indonesia which received 175.4 million people, and estimated in 2010 to be 279.3 million people, in 2020 to 300 million people and in 2030 to 366 million people ${ }^{(7)}$. 
The most common diabetes mellitus in Indonesia is diabetes mellitus type 2. Diabetes mellitus Type 2 is one of the most chronic in elderly clients ${ }^{(16)}$. The diabetes mellitus incidence rate in Banjarmasin from the beginning of 2012 to August 2012 defeated 2,861 people ${ }^{(9)}$. This disease causes reduced insulin production and availability in the body or changes in insulin function that are actually sufficient. The insulin difference results from damage to most or most of the beta cells of the islets of langerhans in the pancreatic relationship that produces insulin ${ }^{(14)}$.

In the long term, diabetes mellitus can cause complications which consist of narrowing of blood vessels that are saved by the body, and impaired nerve function, so that in the end the function of the organs will be disrupted. This reduces the nervous system and blood flow which becomes reduced due to constriction. Abnormalities in nerves and blood vessels are the background of chronic damage complications such as heart attacks, weak heart, stroke, blindness due to eye membranes which can quickly be revived cataracts, medical devices that are repaired blood terminals, blood gauges, abscesses, gangrene that cause reasons hand or foot cutting (amputation), recovery section containing impotence, decreased fertility, often abortion and vaginal discharge, on devices that can cause damage to the stomach application (often bloating), often due to the use of autonomy, which in the end all the previous complications will causing the life expectancy of clients with diabetes mellitus can reduce by about 5-10 years ${ }^{(22)}$.

As for some of the risk factors for type 2 diabetes, namely because of heredity / if there are parents or siblings affected by type 2 diabetes, obesity (overweight), someone with high levels of cholesterol and triglycerides, someone with a relaxed lifestyle (lack of exercise), mothers who give birth to babies weighing more than $9 \mathrm{lbs}$ (about $4 \mathrm{~kg}$ ), stress, a family history of type 2 diabetes clients in families, ethnic groups (Asian or Afro-Karabia) and who have experienced gestational diabetes or impaired glucose tolerance will increase the risk of developing diabetes ${ }^{(4)}$.

Management of diabetes mellitus is generally divided into primary and secondary therapy. Primary therapy, education, diet, and exercise while oral hypoglycemic drugs, insulin and pancreas grafts ${ }^{(13)}$. One of the main pillars of diabetes management is diet. Despite completing research in the field of diabetes treatment with the discovery of various types of insulin and the latest oral medications, diet is still the main treatment in the management of diabetes, especially diabetes mellitus type $2^{(23)}$. Foods or diabetes mellitus diets contain high fiber and low in fat and protein. Fruits and vegetables that are rich in minerals, vitamins, and antioxidants are consumed as part of the $\operatorname{diet}^{(4)}$.

Failure is one obstacle to the treatment of diabetes mellitus. To overcome the bankruptcy of education for people with diabetes mellitus, participants and participants should consider diabetes mellitus for lifestyle-related diseases. People with diabetes mellitus who have enough knowledge about diabetes mellitus, then change their behavior will be able to regulate the condition of the disease so that life becomes more quality. Successful management of independent diabetes mellitus requires active participation of clients, families and communities and the support of a team of educators consisting of doctors, nutritionists, nurses, and other health workers ${ }^{(13)}$.

Various studies have shown that client obedience with the treatment of chronic diseases is generally low ${ }^{(6)}$. According to a WHO report in 2003, the client's average adherence to long-term therapy for chronic diseases in developed countries was only 50\%, whereas in developing countries, the number was even lower ${ }^{(5)}$. Diabetes mellitus clients who have adequate knowledge, attitudes and skills about appropriate dietary standards and apply them in their daily diets are expected to be able to control their weight and blood glucose levels so as to prevent further complications. In implementing a diet on a diabetes mellitus client there are 3 errors that become a problem including a lack of knowledge, forgetting on a diet on time, and a lack of commitment in implementing a diet ${ }^{(13)}$. In addition, family support is very important to motivate clients in taking medication or diet ${ }^{(24)}$.

\section{Research Methods}

This type of research uses Analytical Survey research methods with Cross Sectional approach. This research was conducted at Puskesmas Pekauman Banjarmasin in August 2018 to July 2019. The population and sample in this study were all diabetes mellitus disease clients in 
Puskesmas Pekauman Banjarmasin working area with a total sample of 77 people. The sampling technique in this research is accidental sampling.

Retrieval of data sources using questionnaires, the questionnaire is said to be valid and reliable if the value of $r$ count $>r$ table where for $n=20$ at a significance level of $5 \%$ of the $r$ table is 0.444. Data obtained from the results of the questionnaire is processed with the aim of converting the data into information through stages: Drafting of data, Classification of data, Processing of data, and interpretation of data processing results.

\section{Results}

3.1 Relationship of Knowledge Level with Diet Obedience in Type 2 Diabetes Mellitus clients

Table $3.1 \quad$ Knowledge with Diet Obedience types

\begin{tabular}{lcccccccc}
\hline \multirow{2}{*}{ No } & \multirow{2}{*}{$\begin{array}{c}\text { Knowledge } \\
\text { of level }\end{array}$} & \multicolumn{4}{c}{ obedience } & \multicolumn{2}{c}{ Total } \\
\cline { 3 - 6 } & & \multicolumn{2}{c}{ Not obey } & \multicolumn{2}{c}{ obedient } & & $\%$ \\
\hline 1 & Less & 9 & 11.7 & 2 & 2.6 & 11 & 14.3 \\
2 & moderate & 12 & 15.6 & 10 & 13.0 & 22 & 28.6 \\
3 & Tall & 19 & 24.6 & 25 & 32.5 & 44 & 51.7 \\
\hline & & Total & 40 & 51.9 & 37 & 48.1 & 77 & 100 \\
\hline
\end{tabular}

Primary Data

\subsection{Relationship of Family Roles with Diet obedience}

Table $3.2 \quad$ Knowledge with Diet obedience types

\begin{tabular}{|c|c|c|c|c|c|c|c|}
\hline \multirow{3}{*}{ No } & \multirow{3}{*}{ Family Roles } & \multicolumn{4}{|c|}{ Obedience } & \multirow{2}{*}{\multicolumn{2}{|c|}{ Total }} \\
\hline & & \multicolumn{2}{|c|}{ Not obey } & \multicolumn{2}{|c|}{ Not obey } & & \\
\hline & & $\mathrm{n}$ & $\%$ & $\mathrm{~N}$ & $\%$ & $\mathrm{n}$ & $\%$ \\
\hline 1 & Negative & 22 & 28.6 & 12 & 15.6 & 34 & 44.2 \\
\hline \multirow[t]{2}{*}{2} & Positive & 18 & 23.3 & 25 & 32.5 & 43 & 55.8 \\
\hline & Total & 40 & 51.9 & 37 & 48.1 & 77 & 100 \\
\hline
\end{tabular}

Primary Data

\section{Discussion}

From table 3.1, it can be seen that respondents with a good level of knowledge as many as 25 respondents $(32.5 \%)$ adhere to their diet, while respondents with a good level of knowledge but are not obedient as many as 19 respondents $(24.6 \%)$. This illustrates that with a well-informed client, the client will be increasingly compliant with adherence to the diabetes mellitus diet that he lives.

From the results of the Spearman correlation test (Rho) with a 95\% confidence level, the $\mathrm{p}$ value $=0.036(p<0.05)$ with a correlation value of 0.239 . Then the research hypothesis test says $\mathrm{HO}$ is rejected or Ha is accepted. This means that there is a meaningful relationship between the level of knowledge and diet adherence of clients with diabetes mellitus at Puskesmas Pekauman Banjarmasin.

Client obedience with diabetes mellitus in the implementation of the diabetes mellitus diet is indirectly influenced by the results of knowing clients with diabetes mellitus obtained from 
education. In this study, it will be explained why the results of the lack of knowledge as many as 9 respondents did not comply with the diet with a percentage of $11.7 \%$. this is because in a total sample of 77 respondents, it was found that 21 respondents were primary school educated. A client with a basic level of education, tends to be difficult to accept developments or in terms of new information, especially in supporting the degree of health because there is no sufficient reasoning process due to the educational background they have. Without high knowledge, the client is lazy to comply with the diet program that he runs. On good knowledge as many as 19 respondents did not comply with the diet with a percentage of $24.6 \%$ because they really want to eat food outside the diet program. It is this desire that drives them to become non-compliant with type 2 diabetes mellitus diet programs.

Factors that influence obedience include predisposing factors (predisposing factors), enabling factors (enabling factors), and reinforcing factors (reinforcing factors). Predisposing factors include attitudes, beliefs, beliefs, socio-culture, customs and traditions. Enabling factors include the distance between the house and the health facility, and the available health facilities. While the reinforcing factors (reinforcing factors) include the attitudes of health workers and the behavior of health workers. Knowledge of a diabetes mellitus client which includes the definition, goals, requirements and implementation of the diabetes mellitus diet will indirectly affect the obedience of the diabetes mellitus client in implementing the diabetes mellitus diet ${ }^{(15)}$.

The results of this study are consistent with the opinion that new behavior, especially in adults, begins in the cognitive domain in the sense that the subject knows in advance of stimuli in the form of material objects causing inner responses in the form of attitudes. Finally the stimulus that is the object that has been known and fully realized will lead to a further response in the form of action on the stimulus or object. Knowledge is the initial step of someone to determine their attitudes and behavior. So the level of knowledge will greatly affect the acceptance of a program (15).

Other matters that affect obedience are information, information sources and mass media. By getting the right information, and supported by information conveyed by health workers regarding the implementation of the diabetes mellitus diet and the availability of health facilities and infrastructure that can support the positive behavior of clients with diabetes mellitus in the implementation of the diabetes mellitus diet will affect the attitudes held by clients with diabetes melitus to go on a diabetes mellitus diet as a way to control sugar in the blood. Without this knowledge, clients with diabetes mellitus will be lazy and reluctant to comply in carrying out a diabetes mellitus diet because the client does not know how the impact of non-obedience in implementing a diabetes mellitus diet ${ }^{(16)}$.

Low education level can cause lack of health knowledge. With a low level of education a person will greatly affect one's level of knowledge. Knowledge will also affect a person's behavior, including in the treatment of hypertension. Low knowledge is likely to influence hypertension treatment behavior in dietary regulation ${ }^{(8)}$.

Based on the results of this study indicate that respondents with low knowledge is one of several factors that influence diet adherence in type 2 diabetes mellitus clients in Puskesmas Pekauman Banjarmasin so as to increase knowledge can be obtained through reading, seeing, listening from electronic media or diligently attending seminars on diabetes mellitus. Without knowledge, clients with diabetes mellitus will be lazy and reluctant to comply with the diabetes mellitus diet because the client does not know how the impact of non- obedience in implementing the diabetes mellitus diet ${ }^{(16)}$.

From table 3.2, it can be seen that respondents with negative family roles of 22 respondents (28.6\%) are not compliant with their diets. While respondents with positive family roles were 25 respondents $(32.5 \%)$ compliant with the diabetes mellitus diet. From the Spearman correlation test (Rho) with a 95\% confidence level, the value of $\mathrm{p}=0.047(\mathrm{p}<0.05)$ was obtained with a correlation value of 0.257 . Because the significant value obtained $(\mathrm{p})<\alpha$, then the H0 research hypothesis was rejected and $\mathrm{H} 1$ was accepted meaning there was a significant relationship between the role of the family with adherence to the diabetes mellitus diet at the Puskesmas Pekauman in Banjarmasin.

In the results of the study note that the role of a positive family of 18 respondents were not compliant with the diet with a percentage of $23.3 \%$. From the questions and answers obtained, the 
respondent said that he would abide by the diet program that he runs if he eats or drinks accompanied by his family, whether children, husband, wife, son-in-law or other family members who when he eats and drinks are beside him . In addition, the thing that affects the client's nonobedience with the diet is that the client buys his own food and drinks that should not be eaten and drunk outside the knowledge of family members. So that when finished eating and drinking earlier, blood sugar rises are not on the verge of normal again. In the negative family role, 22 respondents disobeyed the diet with a percentage of $28.6 \%$. the result of the interview is this because remembering that the respondents are mostly female as many as 59 respondents with a percentage of $76.62 \%$. this is what causes family peren become negative, because most of their husbands are workers as laborers, farmers, and traders. Causing a lack of attention, love and affection given results in decreased motivation to maintain health and cure by clients with type 2 diabetes mellitus.

Family support is the closest and most inseparable part of the client. Clients will feel happy and peaceful if they get attention and support from their families, because with this support will lead to confidence to deal with or manage the disease better. Lack of support can reduce client motivation for health care. Whereas better support will increase client motivation for health in terms of regular control and obedience with diet ${ }^{(8)}$.

In this regard, it is necessary to increase positive family support by including the family in each treatment program, in the counseling program and monitoring the diet program and monitoring glucose levels in the blood. And from the results of research that has been done, it is known that the role of the family that plays a positive role will affect the level of client obedience with diabetes mellitus. Aside from positive family support, another factor that might affect clients with diabetes mellitus is the length of illness acquired ${ }^{(10)}$.

The argument above is strengthened by the journal ${ }^{(19)}$, in which the writer argues that family support is low and thus makes the client disobedient, this is because stroke is a chronic disease that takes a long time to cure and creates physical limitations. This is also supported by a statement that argues that given that as many as $20.09 \%$ of respondents have been diagnosed with diabetes mellitus $\geq 5$ years, then this causes the client to feel bored and not following the diet program he has to run. In addition, the length of time the client must comply with the advice given during illness will affect the level of client obedience with the program underway ${ }^{(1)}$.

This is in accordance with the theory of family support is very influential on the health of clients who say that the family is seen as a system, if there is interference with one family member can affect the entire system. Conversely family dysfunction can also be one of the causes of disruption in family members. He also explained the family a source of practical and concrete help, including regularity of therapy, including in terms of food and drinking needs ${ }^{(11)}$.

\section{Conclusions}

Respondents' knowledge is mostly in the good category with a percentage of $51.7 \%$, the role of the family is mostly positive with a percentage of $58.8 \%$, Client obedience with the Diet most of the clients do not comply with the implementation of diabetes mellitus with a percentage of $51.9 \%$, There is a meaningful relationship between Knowledge with diet obedience in Diabetes Mellitus clients and There is a significant relationship between the Role of the Family and Dietary Obedience in Type 2 Diabetes Mellitus clients in Puskesmas Pekauman Banjarmasin.

\section{References}

[1] Anggina, Linggar L, Dkk. Hubungan Antara Dukungan Sosial Keluarga Dengan Kepatuhan Pasien Diabetes Mellitus Dalam Melaksanakan Program Diet Di Poli Penyakit Dalam Rsud Cibabat Cimahi. Jurnal Kesehatan. (2010).

[2] Ardi, Muhammad. Telehomecare Pada Diabetes Melitus Tipe 2. Fakultas Ilmu Keperawatan Universitas Indonesia. (2010).

[3] Arikunto, Suharsimi. Prosedur Penelitian Suatu Pendekatan Praktik. Jakarta: Rineka Cipta. (2006).

[4] Arora, Anjali. (2009). 5 Langkah Mencegah dan Mengobati Diabetes. Jakarta: Bhuana Ilmu Populer. 
[5] Asti, Tri. Kepatuhan Pasien : Faktor Penting dalam Keberhasilan Terapi. Info POM, Vol. 7, No. $5 . \quad$ (2006). 5 dari http:// perpustakaan.pom.go.id/KoleksiLainnya/Buletin\%20Info\%20POM/0506.pdf. (Di Akses, 20 Desember 2012).

[6] Basuki, Endang S. Konseling medik: Kunci menuju kepatuhan pasien. Departemen Ilmu Kedokteran Komunitas. FKUI. (2009).

[7] Darmono. Naskah Lengkap : Diabetes Mellitus Ditinjau dari Berbagai Aspek Penyakit Dalam. Semarang : CV. Agung Semarang. (2007).

[8] Delima Fitri P.N. Hubungan dukungan keluarga dengan kepatuhan diet rendah garam dan keteraturan control tekanan darah pada penderita hipertensi di poliklinik RSUD tugurejo semarang. Jurnal Kesehatan. (2012).

[9] Dinkes Kota Banjarmasin. Data AngkaKejadian Diabetes Melitus Di Seluruh Puskesmas Banjarmasin. (2012).

[10] Erawatyningsih, E. ,Purwanta. \& Subekti, H. Faktor-faktor yang mempengaruhi ketidakpatuhan berobat pada penderita tuberculosis paru. (2009). http://berita-kedokteranmasyarakat.org/index.php/BKM/article/view/170 (Diakses tanggal, 4 Januari 2013).

[11] Friedman M. Keperawatan Keluarga Teori dan Praktek. Jakarta : Edisi 3. EGC. (1998).

[12] Hartini, Sri. Dasar-dasar Pengendalian Diabetes dan Pemakaian Tablet Anti Diabetes. Sub Bagian Endokrinologi-Metabolisme. Bagian I, Penyakit Dalam FK Unpad/ RS Hasan Sadikin, Kumpulan Naskah Simposium Penyuluhan Diabetes Mellitus Dalam Rangka Menyambut Konggres Nasional III Perkumpulan Endokrinologi Indonesia. Semarang. (1993).

[13] Martalena. Pengaturan Makanan Diabetesi. Pusat Diabetes Yogyakart. (2010).

[14] Maulana, Mirza. Mengenal Diabetes Melitus. Yogyakarta : Kata hati. (2009).

[15] Notoatmodjo, Soekidjo. Pendidikan dan Perilaku Kesehatan. Jakarta: PT. Rineka Cipta. (2003).

[16] Pramilih, Dinar. Pola Penggunaan Obat Hipoglikemik Oral (Oho) Pada Pasien Geriatri Diabetes Mellitus Tipe 2 Di Instalasi Rawat Jalan RSUD Dr. Moewardi Surakarta Periode Januari - Juli 2008. Universitas Muhammadiyah Surakarta. (2009).

[17] Purwanto, Nasrul H. Hubungan Pengetahuan Tentang Diet Diabetes Mellitus Dengan Kepatuhan Pelaksanaan Diet Pada Penderita Diabetes Mellitus. Jurnal Kesehatan. (2011).

[18] Rosiana, Eka. Hubungan Dukungan Keluarga Dengan Kepatuhan Menjalani Fisioterapi Pada Klien Pasca Stroke Di Instalasi Rehabilitasi Medik RSUD SlemanYogyakarta. Naskah Publikasi. (2012).

[19] Rusimah. Hubungan Tingkat Pendidikan Dan Pengetahuan Gizi Dengan Kepatuhan Diet Pada Penderita Diabetes Mellitus (Diabetisi) Di Ruang Rawat Inap RSUD Dr.H.Moch Ansari Saleh Banjarmasin Tahun 2010. Skripsi STIKES Husada Borneo. (2011).

[20] STIKES Sari Mulia. Buku Pedoman Penulisan SKRIPSI. Banjarmasin. (2011).

[21] Susilo, Y \& Wulandari, A. Cara Jitu Mengatasi Kencing Manis. Yogyakarta : Andi Offset. (2011).

[22] Wahyudi, Sedyo. Sehat dan Bugar bersama Diabetes. (2009). http://majalahkasih.pantiwilasa.com/index2.php?option=com_content\&do_pdf=1\&id=27 (Diaksestanggal 24 Agustus 2012).

[23] Waspadji, S. Pedoman Diet Diabetes Melitus. Jakarta : FKUI. (2004).

[24] Waspadji, S. Mekanisme Dasar dan Pengelolaannya yang Rasional dalam Penatalaksanaan Diabetes Terpadu. Jakarta : Edisi kelima, Balai Penerbit FKUI. (2005).

[25] Yunitasari, Firda. Hubungan Tingkat Dukungan Keluarga Terhadap Kepatuhan Terapi Diabetes Melitus Tipe 1 Pada Anak Usia 5-14 Tahun Di Rumah Sakit Saiful Anwar Malang. Jurnal Kesehatan. (2012). 